\title{
一ツ葉入江に生息するフタハピンノの生活史について
}

\section{Life cycle of the pea crab Pinnotheres bidentatus living in Hitotsuba Inlet, east coast of Kyushu, Japan}

\author{
小関祥子・富岡 宏 ${ }^{1)}$-三浦知之 ${ }^{2)}$, * \\ （株）日本海洋生物研究所（分室） $\overline{7} 141-0033$ 東京都品川区西品川 1-7-7 \\ 1) (株) 山崎製パン泉佐野事業所 $\bar{T} 580-8504$ 大阪府松原市三宅東 2-1835-5 \\ 2) 宮崎大学農学部 $\bar{T} 889-2192$ 宮崎市学園木花台西 1-1
}

\section{Shoko OZEKI, Hirosi TOMIOKA ${ }^{1)}$ and Tomoyuki MIURA ${ }^{2) * *}$}

\author{
Marine Biological Research Institute of Japan Co. Ltd., Nishi-Shinagawa 1-7-7, Shinagawa, Tokyo 141-0033, Japan \\ 1) Yamazaki Baking Co. Ltd., Izumi-Sano Branch, Miyake-Higashi 2-1835-5, Matsubara, Osaka 580-8504, Japan \\ 2) University of Miyazaki, Faculty of Agriculture, Gakuen-Kibanadai-Nishi 1-1, Miyazaki, Miyazaki 889-2192, Japan
}

\begin{abstract}
The pea crab Pinnotheres bidentatus Sakai, 1939 is a parasite that lives inside bivalve mollusks in brackish waters. In Hitotsuba Inlet on the east coast of Kyushu, Japan, we conducted two sampling surveys of its host bivalves from May, 2004 to September, 2005 and from May, 2011 to July, 2012 to elucidate the life history of the crabs based on their size distribution. The main host bivalves were two psammobiid species, Nuttallia japonica and Psammotaea virescens. While the densities of these bivalve populations in the inlet decreased 25-50\% from 2004 to 2011 , the density of pea crabs did not. The proportion of infested Nuttallia japonica increased from 5.5\% in 2004-2005 to $25.0 \%$ in 2011-2012. In the inlet, the crab Pinnotheres bidentatus spawns from late May to late September, the next generation infests bivalves in fall to winter, and the infested crabs grow until the next spawning season.
\end{abstract}

Key Words: life history, pinnotherid crab, psamobiid bivalve, size-distribution, taxonomy

\section{はじめに}

日向灘に面した宮崎市の中央を流れる大淀川河口には長 さ3 km ほどの潟湖が発達していた。しかし，1981 年に宮 崎港新港の建設が始まり, 1987 年にはその海側の砂嘴が 開削され，北部の $600 \mathrm{~m}$ ほどの小さな入り江を残して港 湾が形作られた. 現在の一ツ葉入り江は港湾建設以前に比 べると，淡水流入の少ない潟湖干潟を形成している，その 総面積は約 12 ha で, 7 ha ほどが干出する (三浦 2013). 港湾建設以前は, 広いコアマモ Zostera japonica Asch. et Graebn. 1907 の藻場が広がり（金丸 1980）, ヤマトシジミ Corbicula japonica Prime, 1864, ボラ Mugil cephalus Linnaeus, 1758，ウナギ Anguilla japonica Temminck \& Schlegel, 1846 などが地域住民の漁獲対象になり, 湖水に面して料亭が並 んでいた（檍地区郷土史編さん委員会 1990）。しかし, 港 湾建設により, 新別府川の淡水の流入がほとんどなくなっ たため，入り江内の生物相も大きく変化した．筆者らは 2002 年以来, この水域で種々の生物調査を行ってきた (三浦ほか 2005; 三浦・森 2008). 現在一ツ葉入り江には

Received 10 March 2014 Accepted 21 May 2014

* Corresponding author

E-mail: miurat@cc.miyazaki-u.ac.jp
甲殼類 67 種，貝類 61 種，鳥類 67 種が確認されている (三浦・森 2008; 三浦・実政 2010).

港湾建設に伴い漁業対象から外れた一ツ葉入り江は，八 マグリ Meretrix lusoria (Röding, 1798) などの大型二枚貝が 豊富になり, 殼長 $8 \mathrm{~cm}$ を超えるような個体も見つかって いたが (三浦ほか 2005)，2005 年ごろから採取業者が目立 つょうになり，従来は少なかった潮干狩りが行われるよう になった。一ツ葉人り江では第 1 著者が宮崎大学在籍中に オチバガイ Psammotaea virescens (Deshayes, 1855) とイソ シジミ Nuttallia japonica（Reeve, 1857）の動態をテーマと して調査し, その際, カクレガニ類が比較的頻繁に見つか ることを確認し, また, 第 2 著者がこのカクレガニ類に焦 点をあてた動態調査を実施した。この間, 5 年のブランク はあるが，漁獲増大による宿貝の密度低下にも関わらず， よく似かよった季節変化などが見られたので，ここに報告 する.

カクレガニ科 Pinnotheridae はマメガニ亜科 Pinnothereliinae およびカクレガニ亜科 Pinnotherinae からなる分類群 で (Ng et al. 2008), 多くの種は一生の一部あるいはほと んどを他生物の体内や棲管内ですますという特異な生活史 を持ち, 二枚貝の外套腔からもよく見つかる. 多くの種の 中で, 宿主特異性が低く, 日本各地で知られるオオシロピ ンノArcotheres sinensis (Shen, 1932) については研究も多 
く, 宿貝の成長に悪影響を及ぼすと考えられている (Asama and Yamaoka 2008; 杉浦ほか 1960; Sun et al. 2006; Yamada et al. 2009; 分類に関しては Campos \& Manning 2001). 一ツ葉 入り江は, 採取される二枚貝の種類も多く, 確認されたカ クレガニ類も複数あるが, 特に生息密度の高いオチバガイ とイソシジミに寄居するフタハピンノ Pinnotheres bidentatus Sakai, 1939 は出現頻度も高いので, 本研究の対象とした.

フタハピンノの原記載地は和歌山県の汽水域であるが (Sakai 1939), その後, 和歌山での記録はなく, 紀伊水道 を挟んだ対岸に位置する徳島県吉野川河口域からの標本に よって再記載されるとともに (Sakai 2000), 九州沿岸での 生息も確認されている（渡部 2012）。利用する宿主はイソ シジミやクチバガイ Coecella chinensis Deshayes, 1855, ソ トオリガイ Laternula (Exolaternula) marilina (Reeve, 1863) 等の二枚貝である。なお，一ツ葉入り江産の個体について は, 同定のため, 徳島県吉野川から得られた個体と形態の 比較を行った。

\section{材料と方法}

フタハピンノの生活史を調べるため，2004 年 5 月 17 日 から 2005 年 9 月 18 日までの大潮干潮時, ほぼ月 1 回, お よび 2011 年 5 月 17 日から 2012 年 7 月 31 日までの大潮干 潮時, ほぼ月 2 回, 宿主二枚貝類の定量採集を行った. 宿 主は主にオチバガイとイソシジミであったため, 事前およ び調查期間中に, これら 2 種の生息密度の高い場所を チェックしながら, 定量調査の採集場所や枠数にも反映さ れるよう努めた．各採集場所で, $50 \mathrm{~cm} \times 50 \mathrm{~cm}$ の方形枠 を用いて深さ $20 \mathrm{~cm}$ まで泥を掘り起こし, $1 \mathrm{~mm}$ のッ シュでろるって残った貝類を採集した. 2011 年以降の調 査では，採集後に貝からカニが抜け出すことが確認できる ように各貝をチャック付きポリ袋に入れて研究室に持ち 帰った。また, 2004 年の冬期は個体密度が低かったため, イソシジミは 2004 年 11 月〜 2005 年 2 月, オチバガイは 2004 年 10 月〜 2005 年 1 月の間, 方形枠 2 個分の採集を 行った。一方, 2011 年以後の調查では, 2011 年 10 月〜 2012 年 5 月までオチバガイの生息密度が低下したため, 方形枠 2 個分の採集を行った.さらに 2012 年 4 月から干 潟に砂の堆積がおこり, 1 地点で干出域が広がり, 宿貝の 採取が困難となったため, 2012 年 7 月より生息密度の高 い地点に移し, 調査を続けた. 宿貝標本は, 全てメスで開 き, カクレガニ類の有無を確認した後, 殼長・殼高・殼幅 の 3 箇所を電動式ノギス (Mitutoyo) で $0.01 \mathrm{~mm}$ まで測定 した。また, 二枚貝の軟体部を肉眼で観察し, 卵巣・精巣 の状態を確認した。

カクレガニ類は種を査定し, 甲幅, 甲長を計測し, 雌 雄, 抱卵の有無を記録した後, 一部は飼育容器に移して生 体を観察し, すべての個体を冷凍庫で涷結した後, $70 \%$ 工 チルアルコールで保存した. カクレガニ類の着底後の生活
史については, Christensen and McDermott (1958), Pearce （1964, 1966）などにより詳細に検討されている. 後者では 脱皮回数や体サイズなどと生活史の関係が, 前者では生活 史段階に関する明瞭な呼称とその特徴までが提示されてい る.しかし, 本研究では野外調査のみによる情報が基本 で, 脱皮回数や行動習性などについてもフタハピンノに関 する予備的な知見がないため, より簡潔に分別することに し, 雌 3 段階, 性判別できない個体および雄に分けた。す なわち，腹部に受精卵を抱えた抱卵雌 ovigerous female, 卵を抱えていない未抱卵雌 non-ovigerous female, 甲が硬く 移動時期と思われるハード期雌 hard-shelled female, 雌雄 の判別が困難な亜成体 sex indeterminable, および雄 male である。 ハード期雌は本研究での暫定的な区分で, ホスト の外套腔内で成長する以前の段階で移動も可能と推定され るが, 性判別できるので, 雌に対してだけ設定した. カク レガニ類の形態観察には実体顕微鏡 (Olympus SZX-12) の他, 鹿児島大学の低真空走査型電子顕微鏡（SEM）を 用いて細部を観察した。SEM 観察用の資料の作成は 70\% エチルアルコールで保存しておいた資料を $80 \%$ ，90\%， $100 \%$ のアルコール系列に各 2 時間ずつ浸した後, 再度 $100 \%$ アルコールに 2 時間浸し, その後, 室温で 24 時間放 置してブタノールに置換し,さらに 24 時間室温中で自然 乾燥させた試料を使用した。

一ツ葉入り江に棲息するカクレガニ類と形態比較を行う ため, Sakai（2000）の再記載論文で使用された標本の産地 である徳島県吉野川河口から得られた標本を用いた。

\section{結果}

\section{フタハピンノの形態による同定}

形態観察材料として 2011 年 7 月 31 日に一ツ葉入江のイ ソシジミから得られた甲幅 $3.8 \mathrm{~mm}$ の雄 1 個体, および 2011 年 2 月 8 日に得られた甲幅 $6.8 \mathrm{~mm}$ の雌 1 個体を用 い, 2012 年 6 月 3 日に吉野川河口の底質から採集された 甲幅 $3.6 \mathrm{~mm}$ の雄 1 個体および 2012 年 9 月 1 日にソトオ リガイから得られて甲幅 $6.1 \mathrm{~mm}$ の雌 1 個体と比較した.

一ツ葉入り江で得られた個体は雌雄ともに甲が丸みを帯 びた四角形でやや甲幅が甲長よりも大きい（Fig. 1A, B). 前縁, 側縁, 後縁に歯やくぼみはなく円滑, 甲面は小さな くぼみが点在し, 胃域に棈円形で褐色の斑が有り中心には 漢数字の「八」のような模様が白く抜けており, 雄で明瞭 だが, 雌では色素の濃さに変異がある。歩行脚は第 2,3 歩脚が最も長く, 続いて第 1 歩脚が長く, 第 4 歩脚が最も 短い. 歩脚の指節は全て短鈎状である. 雄は歩脚に羽毛状 の長毛を備えるが, 雌ではまばらでほとんど無毛に近い部 分もある. 針脚可動指は先端が強く内側に曲がり, 基部に は丸い突起状の 1 歯を持ち, 先端前面には鋸歯状の棘を備 えたとても低い1歯があり（Fig. 1C \& D)，その延長上に は鋭い棘列が先端に向かって並ぶ (Fig. 1D). 不動指は先 

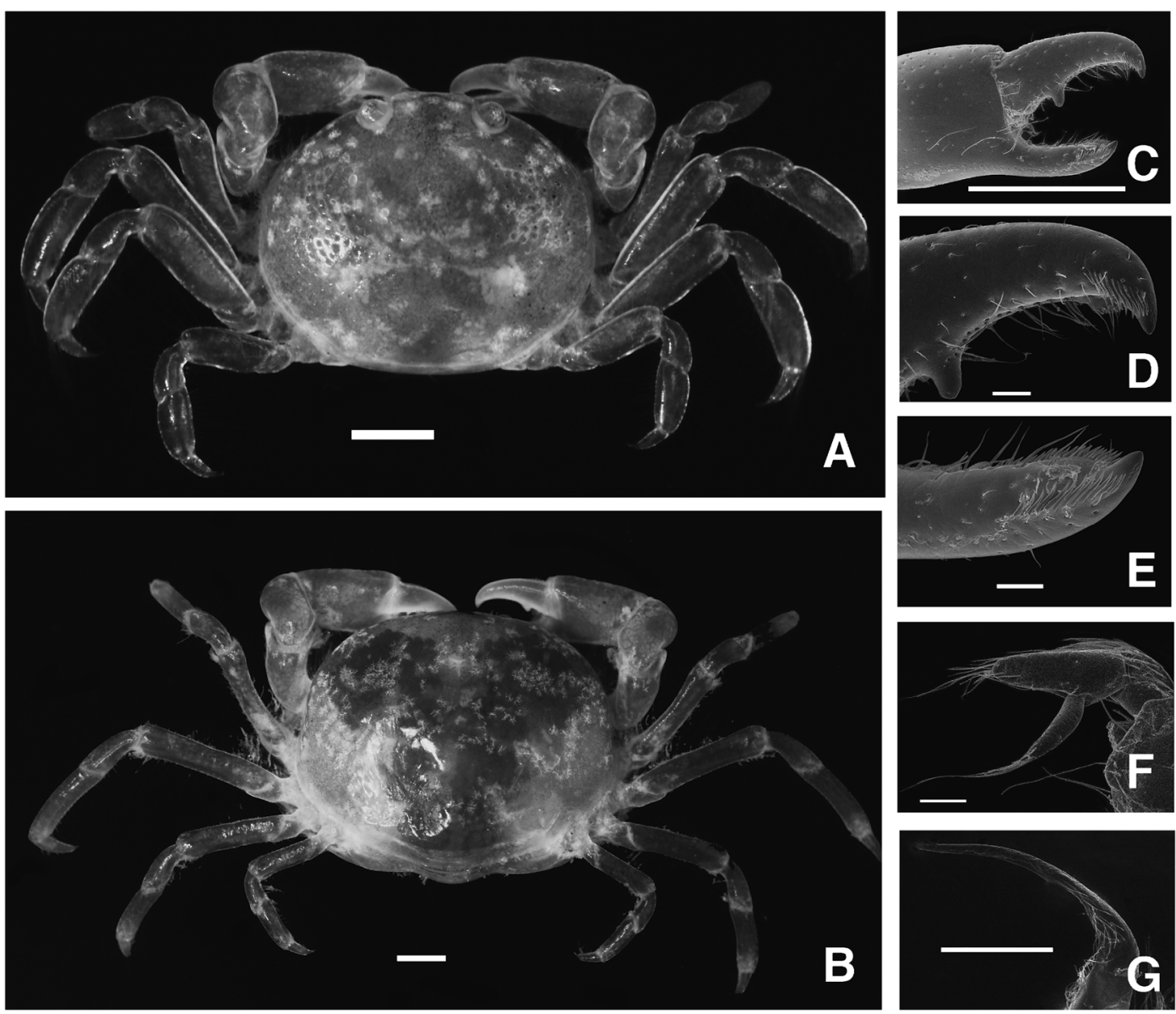

Fig. 1. Pinnotheres bidentatus Sakai, 1939 collected from Hitotsuba Inlet, Miyazaki. A. Male collected on January 8, 2010, carapacd width (CW) $4.1 \mathrm{~mm}$; B. Female collected on May 18, 2011, CW $6.5 \mathrm{~mm}$; C. Left cheliped of a female collected on July 31, 2012; D. Movable finger of the same; E. Immovable finger of the same; F. The third maxilliped of the same female as C-F; G. The first pleopod of the same male as in A. Scale $=1 \mathrm{~mm}(\mathrm{~A}, \mathrm{~B}), 0.5 \mathrm{~mm}(\mathrm{C}, \mathrm{G}), 0.1 \mathrm{~mm}(\mathrm{D}, \mathrm{E}, \mathrm{F})$.

端が細く，基部前面に不明瞭な鈍歯が 3 ないし 4 歯並び, 先端の前後両面に内側に向かう長い棘を各 1 列備える (Fig. 1E). 第 3 顎脚（MXP3）は長節 - 坐節に縫合線がな く完全に癒合しており，内縁はややくぼみ外縁は膨らむ。 指節は前節の基部から伸長し，先端には長毛があり，前節 末端をわずかに越える（Fig. 1F)。雄の第 1 腹肢は先細り， 中ほどから外側に向かって湾曲する。基部から中央まで剛 毛が生える (Fig. 1G).

一ツ葉入江の標本で得られる形態的知見を徳島県吉野川 から得られた雌雄の標本と比較したところ, ほぼすべての 部位について明瞭な差がなかった。このため, これらは同 一の種であると判断した。

第 2 ・3 著者は 2012 年 7 月にタイプ産地の和歌山県内で 採集を試みたが, 標本は得られなかった。また，原記載で 用いられた標本はすでに失われており, 吉野川で得られた 雄を元に再記載が行われている(Sakai 2000). 原記載 （Sakai 1939）と再記載の間に若干の記述の違いがあるもの の, 一ツ葉入江の個体も含めてすべてが個体変異の範囲で あると考えた。これに対して, Sakai（2000）が指摘し, 別
名を与えた台湾産のタイワンピンノ Pinnotheres taichungae Sakai, 2000 は雄の第 1 腹肢の形態において明膫な違いが認 められた（Table 1). 同様に中国の汽水域から記載された チャイナピンノ P. haiyangensis Shen, 1932 とチンタオピン ノP. tsingtaoensis Shen, 1932 は鉗脚不動指の歯が少ないこ となどで明瞭に区別される（Table 1).

\section{宿貝の生息状況とフタハピンノおよび他の寄生者の寄生状況}

6 年の間が開いたいずれの年の調査においても, 一ツ葉 入江での宿貝の採集に当たっては, 環境変化の状況に応じ て枠数や採集場所の変更を何度か行った上で, 高密な生息 地での状況を把握することに努めた. その結果, 貝類の生 息密度は年によっても季節によっても変動することが判明 した。一ツ葉入江で目立つようになったハマグリ等の採捕 により，2005年以降はそれ以前に比べて二枚貝類が目 立って減少した。このことは貝類の生息密度の経時的変化 からも判別できた。すなわち, 貝類の最大生息密度は, 2004 年 7 月から 2005 年 9 月にかけて（Fig. 2 上段左）才 チバガイ（Fig. 2 黒丸）で $1600 \mathrm{~m}^{-2}$, イソシジミ（Fig. 2 
Table 1. Morphological differences in four estuarine species in the genus Pinnotheres.

\begin{tabular}{|c|c|c|c|c|c|c|c|c|c|}
\hline $\begin{array}{c}\text { Species } \\
\text { (specimens) }\end{array}$ & Carapace & Color & $\begin{array}{c}\text { Third } \\
\text { maxilliped }\end{array}$ & Chela & Male pleopod 1 & $\begin{array}{c}\text { Ambulatory } \\
\text { legs }\end{array}$ & Habitat/Host & Locality & References \\
\hline $\begin{array}{l}\text { Pinnotheres } \\
\text { bidentatus } \\
\text { (3 females \& } \\
1 \text { male, lost) }\end{array}$ & $\begin{array}{l}\text { Rounded quad- } \\
\text { rilateral. Lat- } \\
\text { eral borders } \\
\text { slightly di- } \\
\text { vergent back- } \\
\text { ward in fe- } \\
\text { male, parallel } \\
\text { in male. Pos- } \\
\text { terior border } \\
\text { weakly con- } \\
\text { vex }\end{array}$ & - & $\begin{array}{c}\text { Slender dactylus } \\
\text { exceeding tip } \\
\text { of propodus }\end{array}$ & $\begin{array}{l}\text { Movable finger } \\
\text { bearing prox- } \\
\text { imal \& sub- } \\
\text { distal teeth. } \\
\text { Immovable } \\
\text { finger with } 4 \\
\text { or } 5 \text { basa } 1 \\
\text { denticles }\end{array}$ & $\begin{array}{l}\text { Tapering distally } \\
\text { and hairy on } \\
\text { its lateral \& } \\
\text { basal halves }\end{array}$ & $\begin{array}{l}\text { First } 3 \text { pairs } \\
\text { subequal in } \\
\text { length }\end{array}$ & $?$ & $\begin{array}{l}\text { Wakayama, } \\
\text { Japan }\end{array}$ & $\begin{array}{l}\text { Sakai, 1939, p. } \\
\text { 592. text-fig. } \\
78 \mathrm{a}-\mathrm{c}\end{array}$ \\
\hline $\begin{array}{l}\text { Pinnotheres } \\
\text { bidentatus } \\
\text { (a male } \\
\text { sieved out } \\
\text { from } \\
\text { sediment) }\end{array}$ & $\begin{array}{l}\text { Lateral border } \\
\text { rounded in } \\
\text { male, front } \\
\text { slightly pro- } \\
\text { duced, less } \\
\text { deflexed }\end{array}$ & - & $\begin{array}{c}\text { Slender dactylus } \\
\text { exceeding tip } \\
\text { of propodus }\end{array}$ & $\begin{array}{l}\text { Movable finger } \\
\text { bearing prox- } \\
\text { imal \& sub- } \\
\text { distal teeth. } \\
\text { Immovable } \\
\text { finger with } 4 \\
\text { or } 5 \text { near its } \\
\text { base }\end{array}$ & $\begin{array}{l}\text { Slender, } \\
\text { incurved }\end{array}$ & $\begin{array}{l}\text { First } 3 \text { pairs } \\
\text { subequal in } \\
\text { length }\end{array}$ & Male free-living & $\begin{array}{c}\text { Yoshinogawa } \\
\text { River, Toku- } \\
\text { shima, Japan }\end{array}$ & $\begin{array}{l}\text { Sakai, } 2000, \\
\text { pp. } 1156^{-} \\
1158, \text { fig. } \\
1 \mathrm{a}-\mathrm{h}\end{array}$ \\
\hline $\begin{array}{c}\text { Pinnotheres } \\
\text { bidentatus } \\
\text { (many) }\end{array}$ & $\begin{array}{l}\text { Rounded quad- } \\
\text { rilateral. Lat- } \\
\text { eral borders } \\
\text { slightly di- } \\
\text { vergent back- } \\
\text { ward in fe- } \\
\text { male, parallel } \\
\text { in male. Pos- } \\
\text { terior border } \\
\text { weakly con- } \\
\text { vex }\end{array}$ & $\begin{array}{l}\text { Greenish brown } \\
\text { with yellow } \\
\text { spots \& dark } \\
\text { pigments, \& } \\
\text { central large } \\
\text { elliptic spot }\end{array}$ & $\begin{array}{l}\text { Slender dactylus } \\
\text { exceeding tip } \\
\text { of propodus }\end{array}$ & $\begin{array}{l}\text { Movable finger } \\
\text { bearing prox- } \\
\text { imal \& sub- } \\
\text { distal teeth. } \\
\text { Immovable } \\
\text { finger with } 4 \\
\text { or } 5 \text { near its } \\
\text { base }\end{array}$ & $\begin{array}{l}\text { Tapering distal- } \\
\text { ly and hairy } \\
\text { on its lateral } \\
\& \text { basal half }\end{array}$ & $\begin{array}{l}\text { Second ambula- } \\
\text { tory legs lon- } \\
\text { gest. First } \\
\text { shorter than } \\
\text { third. Fourth } \\
\text { shortest. Three } \\
\text { distal seg- } \\
\text { ments with } \\
\text { long and fine } \\
\text { hairs }\end{array}$ & $\begin{array}{l}\text { Nuttallia japon- } \\
\text { ica (Reeve, } \\
\text { 1857), Psam- } \\
\text { motaea vires- } \\
\text { cens (Deshayes, } \\
\text { 1855), P. mi- } \\
\text { nor (Deshayes, } \\
\text { 1885) }\end{array}$ & $\begin{array}{l}\text { Hitotsuba Inlet, } \\
\text { Miyazaki, } \\
\text { Japan }\end{array}$ & $\begin{array}{l}\text { Present study; } \\
\text { Miura, 2008, } \\
\text { p. } 68,5 \text { pho- } \\
\text { tos, as } P \text {. cf. } \\
\text { bidentatus (in } \\
\text { Japanese) }\end{array}$ \\
\hline $\begin{array}{l}\text { Pinnotheres } \\
\text { taichungae }\end{array}$ & $\begin{array}{r}\text { Subcircular, lat- } \\
\text { eral margins } \\
\text { rounded. Small } \\
\text { hollows at } \\
\text { frontal region. } \\
\text { Front margin } \\
\text { with central } \\
\text { to oth from } \\
\text { anterior view. }\end{array}$ & $\begin{array}{l}\text { Greenish with } \\
\text { yellow spots } \\
\& \text { dark pig- } \\
\text { ments, large } \\
\text { elliptic spot } \\
\text { at heart area }\end{array}$ & $\begin{array}{l}\text { Dactylus extends } \\
\text { beyond tip of } \\
\text { propodus }\end{array}$ & $\begin{array}{l}\text { Movable finger } \\
\text { bearing two } \\
\text { large teeth }\end{array}$ & $\begin{array}{l}\text { Middle part curved } \\
\text { outward, with } \\
\text { subdistal long } \\
\text { seta }\end{array}$ & $\begin{array}{l}\text { 4th legs short- } \\
\text { est. Anterior } \\
\text { margin of } 2 \text { nd } \\
\text { \& } 3 \text { rd legs } \\
\text { with short } \\
\text { hair }\end{array}$ & $\begin{array}{l}\text { Laternula }(\text { Ex- } \\
\text { olaternula) } \\
\text { maril in a } \\
\text { (Reeve, 1863) }\end{array}$ & $\begin{array}{l}\text { Kaomei, Taic- } \\
\text { hung County, } \\
\text { Taiwan }\end{array}$ & $\begin{array}{r}\text { Sakai, } 2000 ; \\
\text { originally re- } \\
\text { ported as } P \text {. } \\
\text { bidentatus } \\
\text { by Hsueh \& } \\
\text { Huang, 1996, } \\
\text { pp. 54-57, } \\
\text { figs. 1A-G \& } \\
2 \text { A, B; Hsueh, } \\
2003 \text { as } P \text {. tai- } \\
\text { chungae }\end{array}$ \\
\hline $\begin{array}{l}\text { Pinnotheres } \\
\text { haiyangensis }\end{array}$ & $\begin{array}{l}\text { Anteriorly sub- } \\
\text { quadrilateral, } \\
\text { posteriorly } \\
\text { suborbicular } \\
\text { in female. } \\
\text { Post-frontal } \\
\text { region some- } \\
\text { what depressed } \\
\text { in male }\end{array}$ & $\begin{array}{l}\text { Covered wth } \\
\text { short and fine } \\
\text { lines of soft } \\
\text { blue violet on } \\
\text { ivory yellow } \\
\text { back }\end{array}$ & $\begin{array}{l}\text { Dactylus extend } \\
\text { not beyond } \\
\text { tip of propo- } \\
\text { dus }\end{array}$ & $\begin{array}{l}\text { Movable finger } \\
\text { bearing large } \\
\text { tooth on base. } \\
\text { Immovable } \\
\text { finger nearly } \\
\text { straight on } \\
\text { tip, with very } \\
\text { small tooth } \\
\text { on center }\end{array}$ & $\begin{array}{l}\text { Tapering distal- } \\
\text { ly and hairy } \\
\text { laterally }\end{array}$ & $\begin{array}{l}\text { Second ambu- } \\
\text { latory legs } \\
\text { longest. First } \\
\text { shorter than } \\
\text { third. Four- } \\
\text { th shortest. } \\
\text { Three distal } \\
\text { segments with } \\
\text { long and fine } \\
\text { hairs }\end{array}$ & $\begin{array}{l}\text { Laternula liau- } \\
\text { taudi (Mittre, } \\
\text { 1844) as Ana- } \\
\text { tinia peichi- } \\
\text { hliensis Gra- } \\
\text { bau \& King, } \\
1928 \text { (Later- } \\
\text { nulid bivalve) }\end{array}$ & $\begin{array}{l}\text { Shantung Pen- } \\
\text { insula, China }\end{array}$ & $\begin{array}{l}\text { Shen, 1932, pp. } \\
145-149 \text {, text- } \\
\text { figs, } 89-91 \text {, } \\
\text { pl. 6, figs. } 8 \\
\text { \&9}\end{array}$ \\
\hline $\begin{array}{l}\text { Pinnotheres } \\
\quad \text { tsingtaoensis }\end{array}$ & $\begin{array}{l}\text { Suborbicular and } \\
\text { front truncate } \\
\text { in female. } \\
\text { Front with me- } \\
\text { dian groove in } \\
\text { male }\end{array}$ & $\begin{array}{l}\text { Pale orange yel- } \\
\text { low }\end{array}$ & $\begin{array}{l}\text { Dactylus broad- } \\
\text { ened distally, } \\
\text { extend much } \\
\text { beyond tip of } \\
\text { propodus }\end{array}$ & $\begin{array}{l}\text { Movable finger } \\
\text { bearing large } \\
\text { tooth on its } \\
\text { base. Immov- } \\
\text { able finger } \\
\text { with some } \\
\text { small teeth } \\
\text { on its base }\end{array}$ & $\begin{array}{l}\text { Tapering distal- } \\
\text { ly and hairy } \\
\text { laterally }\end{array}$ & $\begin{array}{l}\text { Second ambula- } \\
\text { tory legs lon- } \\
\text { gest. Fourth } \\
\text { shortest }\end{array}$ & $\begin{array}{l}\text { Laternula liau- } \\
\text { taudi as Ana- } \\
\text { tinia peichi- } \\
\text { hliensis \& } \\
\text { Mactra quad- } \\
\text { rangularis } \\
\text { Reeve, } 1854 \\
\text { as Trigonella } \\
\text { quadriangu- } \\
\text { laris (Reeve, } \\
\text { 1854) }\end{array}$ & $\begin{array}{l}\text { Liaotung \& Shan- } \\
\text { tung Peninsula, } \\
\text { China }\end{array}$ & $\begin{array}{l}\text { Shen, 1932, pp. } \\
\text { 149-151, text- } \\
\text { figs, 92-94, } \\
\text { pl. 6, figs. } 10 \\
\text { \& } 11\end{array}$ \\
\hline
\end{tabular}



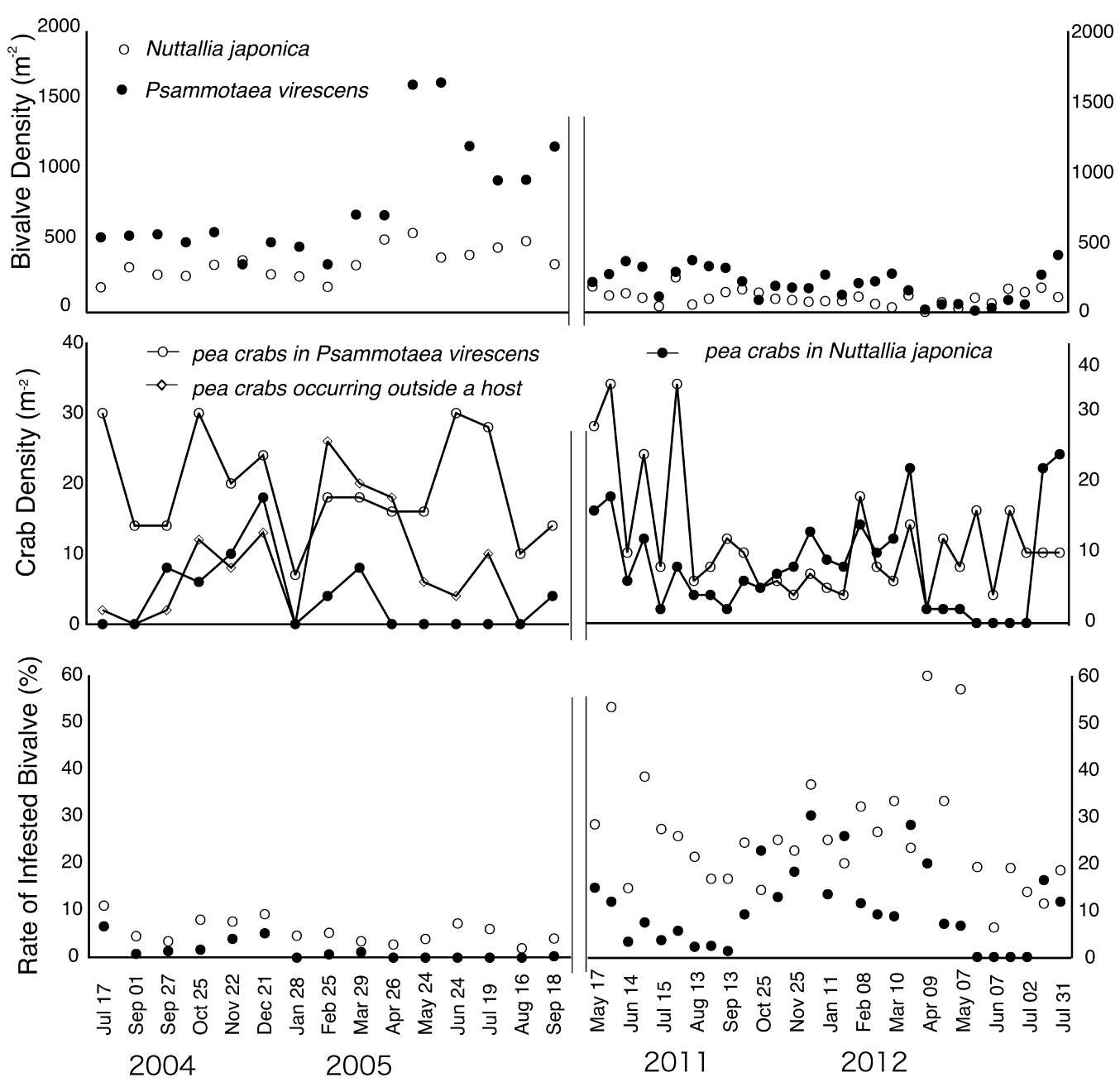

Fig. 2. Seasonal change in the density $\left(\mathrm{m}^{-2}\right)$ of two major bivalves (upper) and the parasite pea crab, Pinnotheres bidentatus (middle; lined marks) living in Hitotsuba Inlet, and the appearance ratio (\%) of infested bivalves (lower), during two different periods from July 2004 to September 2005 (left) and from May 2011 to July 2012 (right).

白丸）で 570 個体 $\mathrm{m}^{-2}$ ほどであったが，2011 年 5 月以降

(Fig. 2 上段右) はオチバガイで 370 個体 $\mathrm{m}^{-2}$, イソシジミ で 250 個体 $\mathrm{m}^{-2}$ 以下でしかなかった。両種とも 6 年の間 に $2 \sim 4$ 分の 1 に減少した. 季節的な変動も 1 回目の調査 の方が大きいが，最低密度はイソシジミの 200 個体 $\mathrm{m}^{-2}$ ほどであった。これに対して, 2011 年以降は, 砂の堆積 などで，両種とも数個体しか採集できないこともあった.

2004 年 7 月から 2005 年 9 月まで 3300 個体のオチバガ イから 22 個体のフタハピンノを，3366 個体のイソシジミ から 181 個体のフタハピンノを得た。なお, 宿主の特定で きないフタハピンノも 89 個体採取された。また, 2004 年 9月には八ザクラガイ Psammotaea minor (Deshayes, 1885) からフタハピンノ雄 1 個体が採集されている. 2011 年 5 月から 2012 年 7 月には, オチバガイ 1422 個体からフタハ ピンノ 147 個体を，イソシジミ 763 個体から 190 個体を, およびオキシジミ Cyclina sinensis (Gmelin, 1791) 64 個体 から 2 個体，フタハピンノは合計 339 個体を採取した。な お，底質中からも 9 個体を得た. 2011 12 年の調査では
フタハピンノの複数寄生も確認できた。宿主となった 337 個体のオチバガイとイソシジミのうち, 311 例は雌雄いず れかの単独寄生で, 13 例で 2 個体のフタハピンノが見つ かった。その組み合わせは雌雄各 1 個体が $5 \sim 7$ 月に採集 されたイソシジミ 8 例とオチバガイ 3 例で, 雄 2 個体が 2012 年 5 月 21 日採集のイソシジミの 1 例あった.

これらの数值から, 野外におけるフタハピンノの生息密 度を算出すると 2004 年から 2005 年のオチバガイ生息域で 平均 $3.9(0 \sim 8)$ 個体 $\mathrm{m}^{-2}$ (Fig. 2, 中段左黒丸), イソシ ジミ生息域で平均 19.3（7～30）個体 $\mathrm{m}^{-2}$ であり（Fig. 2, 中段左白丸), 現場で二枚貝を密封しなかったために, 同 じコドラートで宿主不明のフタハピンノも両地域の平均で 8.3（0〜26）個体 $\mathrm{m}^{-2}$ 確認された（Fig. 2, 中段左四角). これに対して，2011 年から 2012 年には, 現場でチャック 付きの袋に宿主を密封したため, 宿主不明のフタハピンノ はほとんど無く,オチバガイ生息域で平均 8.2（0～22）個 体 $\mathrm{m}^{-2}$ (Fig. 2, 中段右黒丸), イソシジミ生息域で平均 11.7 (4 34) 個体 $\mathrm{m}^{-2}$ であった（Fig. 2, 中段右白丸）. 
最初の調査では宿主をしっかり密封しなかったため, 宿主 不明のフタハピンノの割合が高くなってしまった。これら を考慮すると, 宿主の密度低下に関わらず，いずれの調査 でもフタハピンノの生息密度には大差なく, 年による変動 は少ないと考える，ただし，いずれの調査でも，季節によ る変動は激しかった。

宿貝の激減に対して, フタハピンノの生息密度が大きく 変化しなかったことは, フタハピンノの寄生率を平均的に 高くしたと思われる (Fig. 2, 下段)。すなわち，2004〜 2005 年の調査ではオチバガイに対するフタハピンノの調 査日毎の寄生率は最大 $5.2 \%$ (9/174) で, 平均すると $0.7 \%$ （22/3366）に過ぎない，また，イソシジミへの調査日毎の寄 生率は最大 $11.2 \%(24 / 214)$ で, 平均では $5.5 \%$ (181/3300) であった。ただし,この数值は宿主のわからなかった 89 個体も採集されたことを考慮すると, 最大二倍程度の 幅があるものと思われる。これに対して，2011 年以降は， 平均寄生率はオチバガイ $10.3 \%$ (147/1422), イソシジミ 25.0\%（191/763）ではるかに高い值を示した.また，2回 目の調査では, いずれの宿主においても, 寄生率が大きく 変動した (Fig. 2, 下段右).

採集調査を通して，オチバガイとイソシジミの棲息して いる底質中の深さなどでは見つかるフタハピンノの出現な どには違いは感じられなかったが，より墚く潜るオキシジ ミなどでの寄生率 $3.1 \%(2 / 64)$ は高くなかった。フタハ ピンノ以外には, イソシジミとオキシジミの外套腔から, マルピンノ Pinnotheres cyclinus Shen, 1932 の雄が確認され た。一ツ葉入り江では，ハマグリにも確認されているが, 標本を得ることができなかった。

\section{宿貝の生活史}

一ツ葉入江でのオチバガイとイソシジミの個体群の変動 を解析するため, 2004 年から 2005 年にかけて両種の殼長 組成を連続観察した. $3 \mathrm{~mm}$ 幅でのヒストグラムを作成し

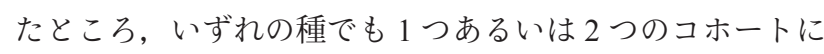
分かれることがわかった。

オチバガイ（Fig. 3）では殼長 $9 \mathrm{~mm}$ 以下の貝が 3 月以 降, 急速に増える. 2005 年 3 月には $9 \mathrm{~mm}$ 以上のオチバ ガイに対して, 殼長 $9 \mathrm{~mm}$ 未満の小型オチバガイが明らか な小型個体のコホートとして確認された．小型個体はすで にわずかながら 2 月には底生生活に入ると考える.この時 期には殼長 9 $15 \mathrm{~mm}$ を境にコホートが 2 つ確認される. 4 月以降も同様に加入個体のコホートと越年したと思われ るコホートが確認されるとともに, 7 月には $6 \mathrm{~mm}$ 未満の 個体の加入がほぼ見られなくなる.この時期以後には大型 個体のコホートが縮小し，モードが1つしか確認されなく なる. 8 月から 9 月には個体が大きく成長し, 個体群とし てはモードが 18〜24 mm を維持して越年する. 従って, オチバガイのほとんどの個体が底生生活する期間は冬 2 月 ぐらいから翌々夏 7 月ぐらいまでの 1 年半程度であると推

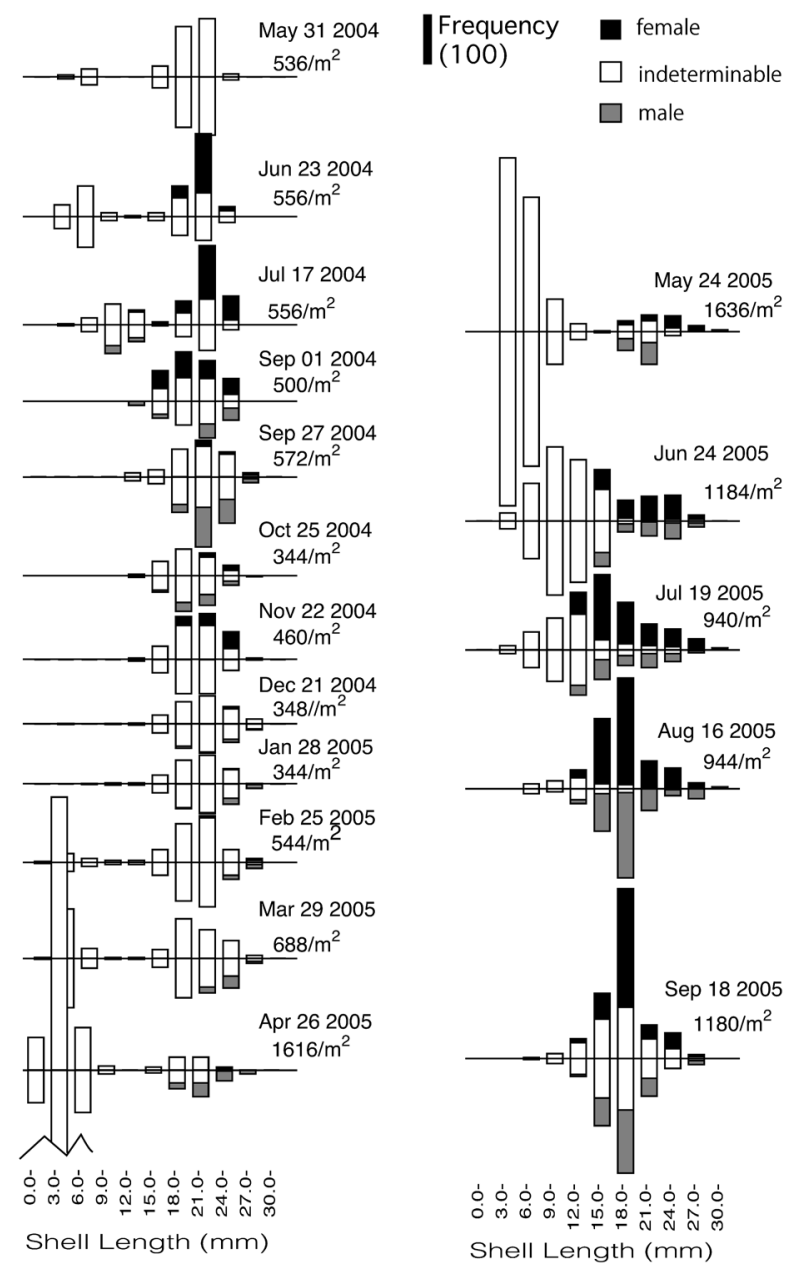

Fig. 3. Size frequency distributions of shell length of a major crab-host bivalve species, Psammotaea virescens from May 2004 to September 2005 in Hitotsuba Inlet, Miyazaki. The sampling date and the bivalve number estimated for a square meter after one or two samples using a quadrat of $50 \mathrm{~cm} \times 50 \mathrm{~cm}$ are shown. Sexed bivalves are shown separately; females (upper), males (lower).

定された. 成熟個体の出現から判断した繁殖時期は 5 月か ら 10 月ぐらいまでであると考える.ただし, 雄の $25 \%$ 以 上が成熟する時期を繁殖の盛期と仮定すると，9月までと なる。 また, 冬に定着した個体の一部は 6〜 7 月以降には, 殼長 $15 \mathrm{~mm}$ 程度まで成長し, 繁殖に参加していると思わ れる. 底生個体だけの調査では初期生活史の数ヶ月から半 年が不明のまま, 今後の課題として残された。オチバガイ は暖かい時期に急速に成長する反面, 冬期の間は成長が停 滞するか, 大型個体が死亡するため成長が見られなくなる と判断され，その寿命は浮遊期を含めても 2 年以内と思わ れる.

イソシジミ（Fig. 4）ではオチバガイと異なり，1年中 成熟した個体が見つかる。 ただし, イソシジミと同様に雄 の $25 \%$ 以上が成熟する時期を繁殖の盛期と仮定すると， 7 月を除いた，5～6月および 8〜 10月が盛期と考えられる. 繁殖の主群は越年したコホートで形成され，そのモードは 


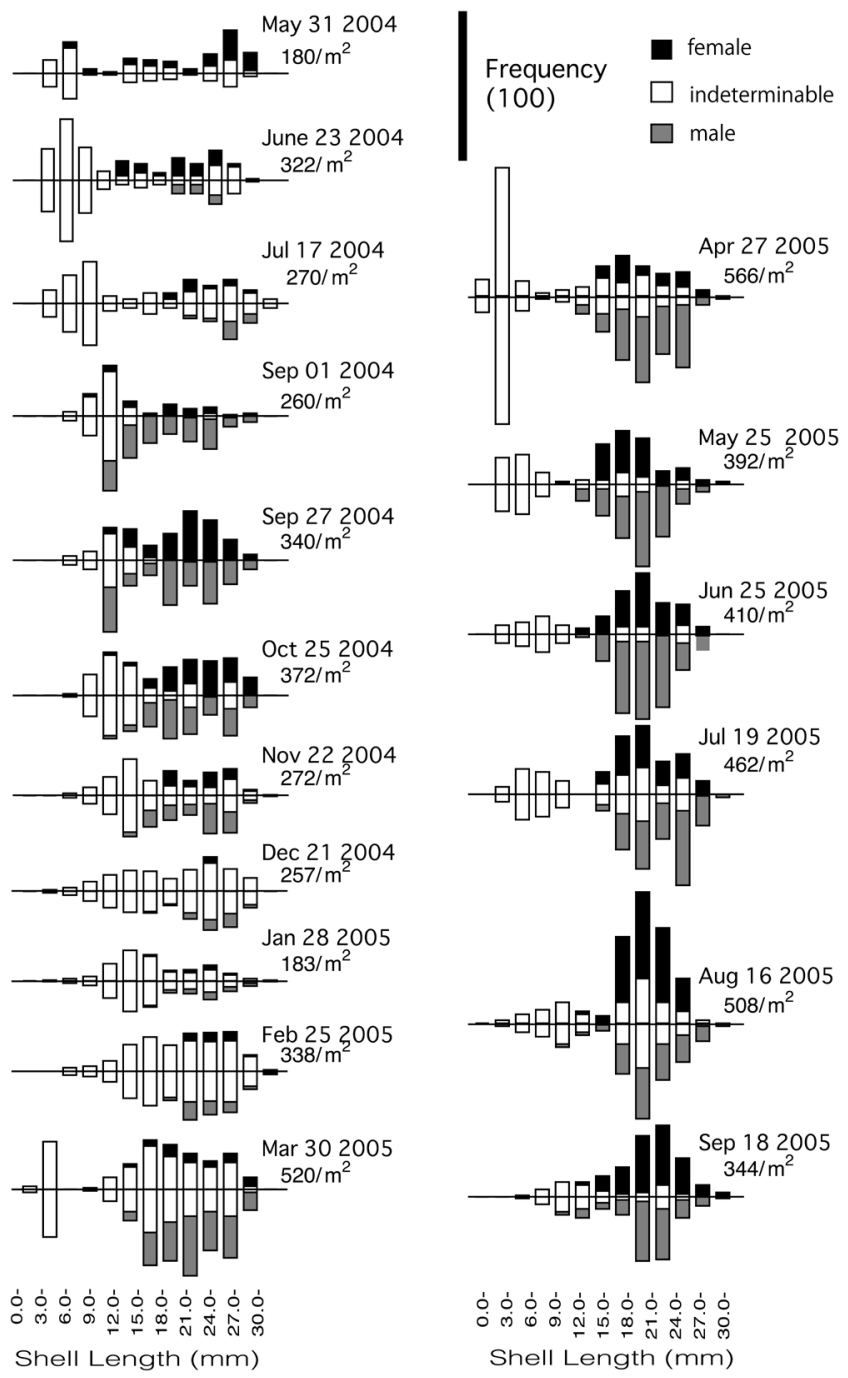

Fig. 4. Size frequency distributions of shell length of another major host bivalve species, Nuttallia japonica from May 2004 to September 2005 in Hitotsuba Inlet, Miyazaki. The sampling date and the bivalve number estimated for a square meter after one or two samples using a quadrat of $50 \mathrm{~cm} \times 50 \mathrm{~cm}$ are shown. Sexed bivalves are shown separately; females (upper), males (lower).
$18 \mathrm{~mm}$ 以上である。これらの個体の繁殖は春から秋まで 続くと思われ, 当年の春に着底した個体も, その一部は半 年後の 9〜 10月に $15 \mathrm{~mm}$ 以上まで成長し，繁殖にも参加 できると思われる。春に着底した個体は，年内に殼長 $15 \mathrm{~mm}$ を超えた後，翌春までには殼長 $21 〜 24 \mathrm{~mm}$ 程度に 達することから，一ツ葉入り江のイソシジミの年間成長量 が極めて大きいことがわかった。一ツ葉入江ではイソシジ ミの大型個体が殼長 $36 \mathrm{~mm}$ を超える。しかし，その比率 は低く，それ以上大型になる前に何らかの原因で死亡する ものと思われる。宮崎県内でも他の干潟では $50 \mathrm{~mm}$ 近く に達するイソシジミも珍しくはないことを考えると，栄養 や底質環境あるいは他二枚貝との競合などの生態的な要因 が影響しているものと考えられる。なお，本研究で得られ た結果だけから判断すると，一ツ葉入江ではイソシジミの ほとんどの個体がオチバガイと同程度の寿命（底生 1 年 半，浮遊期も含めて 2 年以内）を持っていることおよび一 部の個体だけが生残し， 2 年以上生きることがあるものと 思われる。

\section{フタハピンノの生活史}

フタハピンノは一ツ葉入江では 4 種の二枚貝を宿主とす るが，オキシジミ，イソシジミ，オチバガイ，ハザクラガ イの殼長に対するフタハピンノの甲幅の関係あるいは貝の 容積に替わる数值（殼長 $\times$ 殼高 $\times$ 殼幅）との関係を調べて も，相関がないことが判明した（Fig. 5).いずれの貝で も, 殸長が $20 \mathrm{~mm}$ 以上の二枚貝に小型から大型のフタハ ピンノがほぼ一様に分布する。もちろん，小型の貝に大型 のカニが入り込むことはないため, 多少は右肩上がりの分 布になる。また，一部の小型のカ二が小さいオチバガイ， イソシジミ，ハザクラガイに寄生している状況もあるが, 小型のカニは小型の貝を選択しているわけではなく，甲長 $2 \mathrm{~mm}$ ほどのカニは殼長 $40 \mathrm{~mm}$ 程度までの二枚貝に入り込 んでいた.

しかし，例数の多いイソシジミとオチバガイについて検
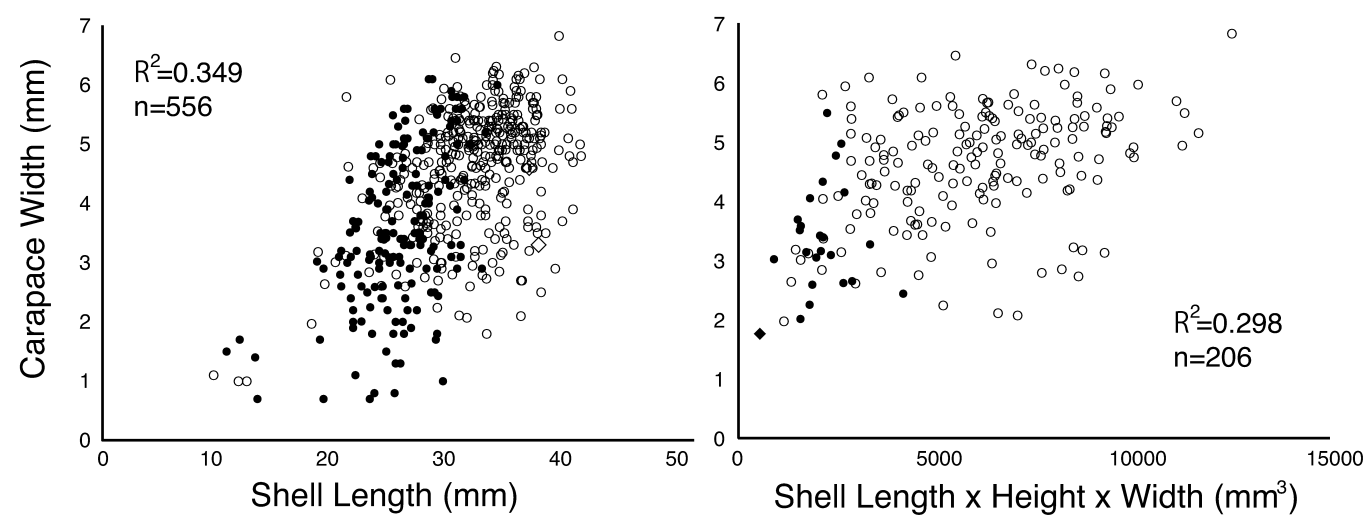

Fig. 5. Relationships between the sizes of host bivalve and its parasite captured in the tidal flat of Hitotsuba Inlet from July 2004 to September 2005 and from May 2011 to July 2012. (left): Correlation between the shell length of three host bivalves and the carapace width of the pea crab, Pinnotheres bidentatus; (right): Correlation between the shell chamber space represented by the multiplication of shell length, shell height and shell width, and the carapace width of the pea crab. Open circle: Nuttallia japonica; closed circle: Psammotaea virescens; closed diamond: Psammotaea minor. 


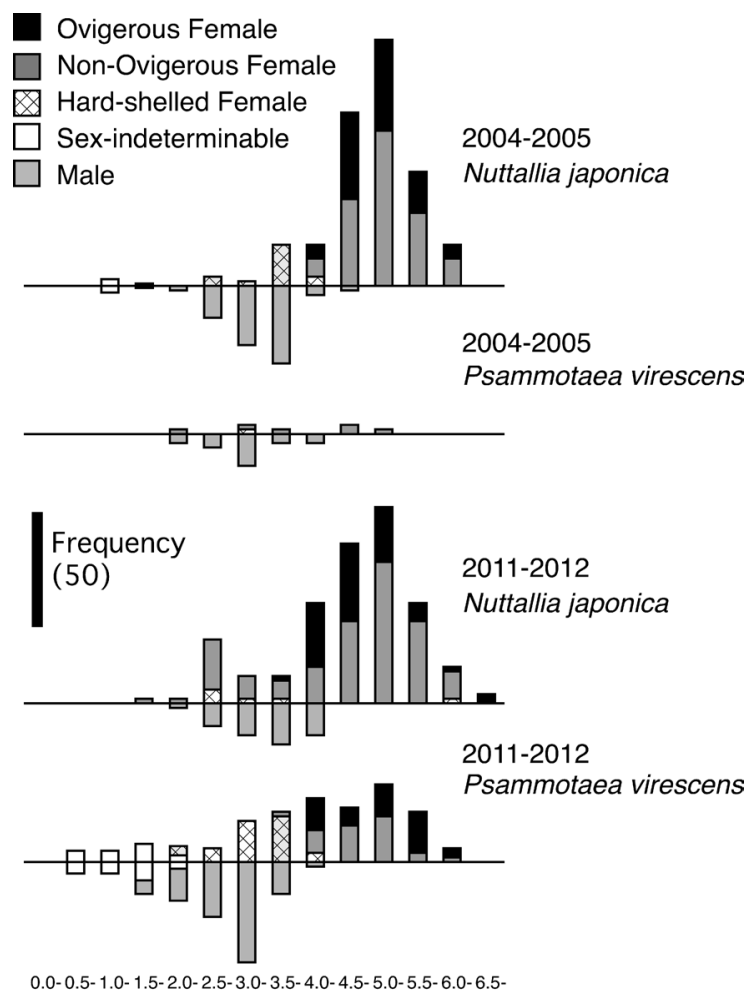

Carapace Width $(\mathrm{mm})$

Fig. 6. Size frequency distributions of carapace width in the pea crab parasitic on two bivalve species captured in the tidal flat of Hitotsuba Inlet, Miyazaki Prefecture, from July 2004 to September 2005 and from May 2011 to July 2012. Sexed crabs are shown separately; females (upper), males (lower).

討したところ, フタハピンノの生活史の中で, 宿貝の利用 が多少異なっていることも判明した（Fig. 6).2004〜 5 年 と 2011〜12 年のいずれの調査でも，オチバガイよりイソ シジミに寄生するフタハピンノで甲幅 $4 \mathrm{~mm}$ 以上の大型の 雌が多く出現した。2 2011 年の調査ではオチバガイにも抱 卵䧳が出現したが，2004〜 5 年の調査では出現していな い.これはフタハピンノの雌が成熟するためにはある程度 大きな貝の中で成長する必要があり, 一ツ葉入り江ではイ ソシジミの存在がフタハピンノ個体群の維持に欠かせない 生息環境になっていると思われる. 2011〜 12 年に比べ, 二枚貝の生息密度がおおよそ 2 4 倍であった 2004〜 年 にはフタハピンノが利用できるイソシジミが豊富で, 雌は 移動時期に容易にイソシジミに到達できたと考えられる. また，オチバガイの中で成長する必要もなかったのであろ う. 反面, 2011〜12 年にはイソシジミなどの大型の宿貝 が少なく，オチバガイにも雌が残り，抱卵したものと考え る. ほとんどの雄は甲幅 $4 \mathrm{~mm}$ 以下であり，いずれの年も オチバガイ・イソシジミの両宿主に同じように出現するた め, 成長のためにはいずれの貝でも必要な栄養と生息空間 が得られるようである。

各調査時のフタハピンノ標本数は少ないが, すべてのフ

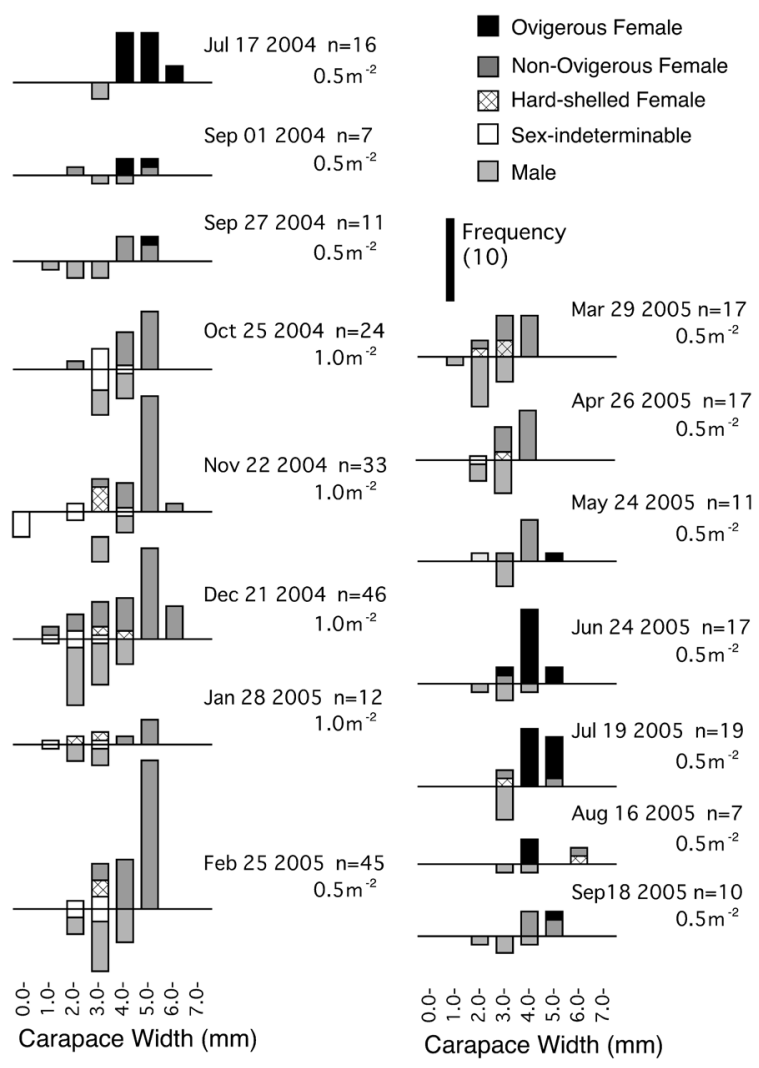

Fig. 7. Size frequency distributions of carapace width in the pea crab Pinnotheres bidentatus, parasitic on two major bivalve hosts captured from May 2004 to September 2005 in Hitotsuba Inlet, Miyazaki. Sampling date and number of pea crabs for 0.5 or $1.0 \mathrm{~m}^{-2}$ are shown. Sexed crabs are shown separately; females (upper), males (lower).

タハピンノを一ツ葉入り江の同じ個体群として繁殖時期や 新規加入に関する情報を得るため, 甲幅ヒストグラムを作 成した，その際，性判別できない稚ガニは雌雄同数である ものとして扱い, 調査ごとのサイズ組成を求めた（Figs. 7 $\& 8)$.

2011〜 12 年調査での性判別できない稚ガニの甲幅は 0.7〜 $2.0 \mathrm{~mm}$, 平均 $1.4 \mathrm{~mm}$ であった. 稚ガニ期の後, 甲が石灰 化し，ハード期に達する頃には性分化すると思われるが, ハード期の雌雄は形態的に酷似しており, 腹肢の形状での み判別できた。雌雄ともに硬い甲殼を持ち, 歩脚に遊泳毛 を備え，宿主を出入できると思われる。ハード期雌の甲幅 は $2.2 \sim 4.4 \mathrm{~mm}$, 平均 $3.4 \mathrm{~mm}$ であった。雌はハード期の 後, さらに成長し, 腹節は体の腹面を顎脚の一部まで覆 い，大きい場合は背面から見えるほど肥大化した。この時 期の抱卵していない雌の甲幅は $3.9 \sim 6.5 \mathrm{~mm}$, 平均 $5.1 \mathrm{~mm}$ であった．色彩には個体差があり，薄い茶褐色で体内の器 官が透けて見えるものが多かった。また，歩脚の遊泳毛は 抜けている個体が多く, 遊泳行動はあまり見られなかっ た. 雄ではハード期以後も形態的には変化がなく, 雄の甲 幅は $1.8 \sim 4.8 \mathrm{~mm}$, 平均 $3.1 \mathrm{~mm}$ であった.

フタハピンノの抱卵雌は 2005 年も 2012 年も 5 月下旬に 


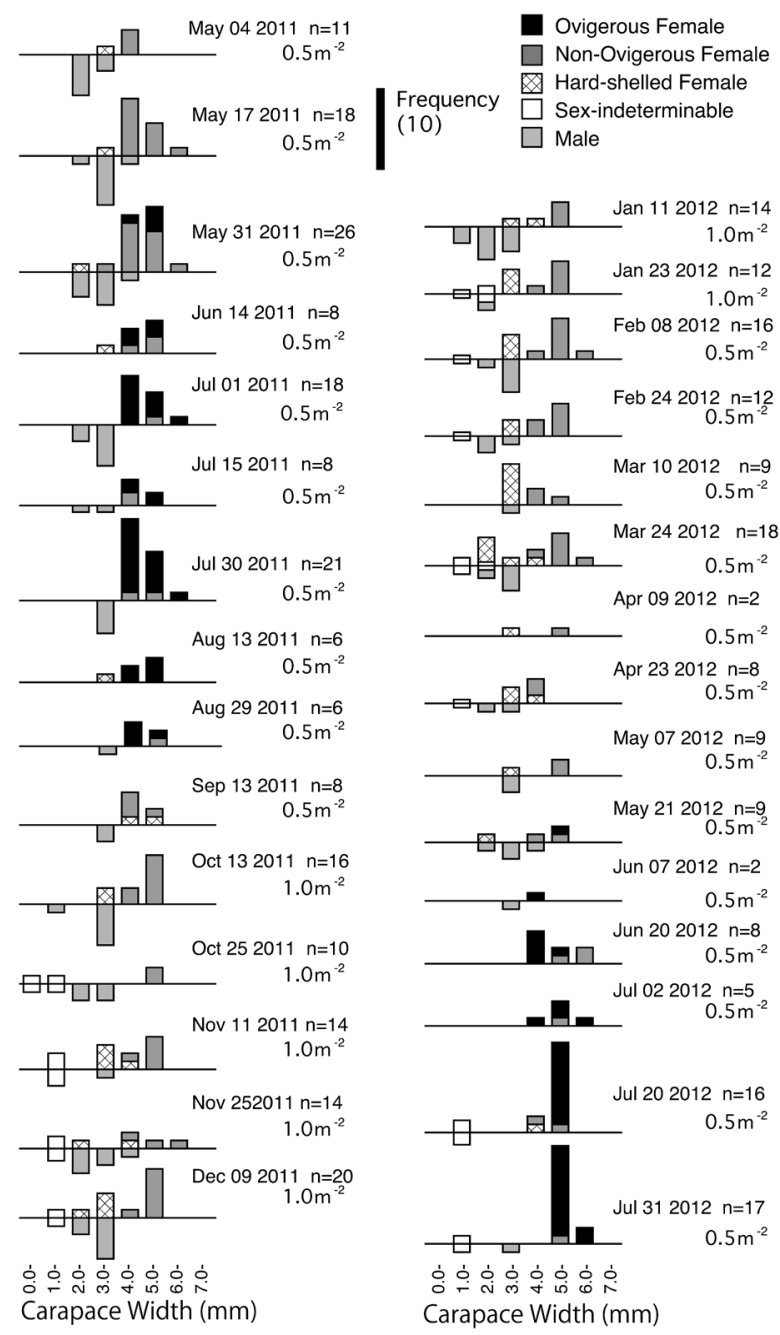

Fig. 8. Size frequency distributions of carapace width in the pea crab Pinnotheres bidentatus, parasitic on two bivalve species captured from May 2011 to July 2012 in Hitotsuba Inlet, Miyazaki. Sampling date and number of pea crabs for 0.5 or $1.0 \mathrm{~m}^{-2}$ are shown. Sexed crabs are shown separately; females (upper), males (lower).

確認されている（Figs. 7 \& 8)．また，いずれの調査でも 9 月下旬までは抱卵雌を確認できるが，10月には抱卵個体 が見つからなくなる。この時期は, 宿貝の生息する底質中 の温度が, 急激に上昇して泥中の水温がほぼ $22^{\circ} \mathrm{C}$ を超え る時期，もしくは，下降して $20^{\circ} \mathrm{C}$ 以下に下がる時期に一 致している．稚ガニを含む甲幅 $1 \mathrm{~mm}$ 台の個体は 9 月もし くは 10 月（2012 年は 7 月から）には確認できるため, 上 記の抱卵雌が 5 月下旬以降に放出した幼生が数ヶ月以内で 寄生生活を始めると推定される. 幼生期がどの水域でどの ように過ごされるかは不明である。

フタハピンノの個体数は季節によって変動し, 甲幅 $2 \mathrm{~mm}$ 程度の小型個体あるいは八ード期の雌は秋から冬に 多い傾向がある. 特には 2011 年以降の調査では, 10 月以 降，翌年 5 月までほぼ 2 週おきの調査ごとに採集されてい る（Fig. 8)。そのため, 秋から春までの間は, フタハピン
ノが宿貝や底質を移動して, 適切な宿主や交尾相手を求め ている可能性が高い．雌に比較すると貝への寄生個体が 1 年を通して少ない雄についても，その増減には雌と同様の 傾向が見られ，10月以降の水温の低い季節に二枚貝の中 に多く見つかる傾向があった。

\section{考察}

ソトオリガイを宿主とするタイワンピンノは，発表時に は台湾産のフタハピンノとして紹介されたが（Hsueh \& Huan 1996)，現在は日本産種とは異なる種とされている (Sakai 2000). 本種については, 台中市の大甲渓河口の個 体群に関する詳細な研究が行われ（Hsueh 2001a, 2001b, 2003), 殸長 $25 \mathrm{~mm}$ 以上のソトオリガイが宿主とされてい る（Hsueh 2003）。大甲渓で他にどのような二枚貝がタイ ワンピンノに利用されているかは不明であるが，一ツ葉入 江には 1 年中複数種の二枚貝が見られ，イソシジミ，才チ バガイ，八ザクラガイからもフタハピンノが見つかってい る.また，一ツ葉入り江にはソトオリガイやムラサキガイ Soletellina adamsii Reeve, 1857 が生息し（三浦ほか 2005）, アシベマスオ S. petalina (Deshayes, 1855) も侵入している ことが判明し（氏野・三浦 2011），利用可能と思われる二 枚貝相が複雑であるが, 現在までこれらの二枚貝ではフタ ハピンノが見つかっていない.

一ツ葉入江でフタハピンノの重要な宿主と考えられるイ ソシジミ属は, 日本産が 3 種とされ（Roth 1978; 4 種に分け る場合もある), 広く北海道南部から中国大陸まで分布し， 食用となり，一般に殼長 $40 \mathrm{~mm}$ を超える。しかし，一ツ葉 入江では大型の個体がほとんど見られなかった。 その反 面, 成長は早く, 宮城県名取川河口での年間成長量 $13 \mathrm{~mm}$ （伊藤 2002）より，三重県安濃川での $20 \mathrm{mm（Miyawaki} \mathrm{\&}$ Sekiguchi 1999）に近い值だと思われる，オチバガイに関 しては既知の情報はないが, 本研究のイソシジミに比較し て, 温かい時期だけ成長して, 冬季に成長が停滞する点は 異なっていた。いずれにしろ，大甲滛河口域とは異なり， これら宿貝となる二枚貝が一ツ葉入り江では 1 年中見られ るが, 漂砂の堆積などさまざまな環境要因により変動する 宿主個体群の動態がフタハピンノの個体群に影響している と考えられる.

台湾の西海岸に生息するシオサザナミガイ科二枚貝 Soletellina acuta (Cai \& Zhuang, 1985) の 90\%以上に寄生する チンタオピンノでは雄が雌の寄居する宿主内で交尾すると 考えられている (Soong 1997).オオシロピンノでは雄の 群泳が確認される一方で, 成熟した雌を宿主外で確認でき なかったため, 宿主内での交尾が示唆されている（Asama and Yamaoka 2009). フタハピンノの群泳行動は一ツ葉入 り江では確認できず，成熟した雌個体が二枚貝に侵入する ことも飼育下では確認できなかったために（富岡ほか未 発表)，本種は宿主内で交尾を行うと思われる。このよう 
な繁殖を反映するように，単一個体の宿主に複数のカクレ ガニ類が寄居することが，いくつかの種で確認されてい る。例えば，ムラサキインコ Septifer virgatus（Wiegmann, 1837）に寄居するオオシロピンノでは年によって変動はあ るものの, 約 10-18\%の宿主において複数のカクレガニ類 が見つかっているが, 雄雌各 1 個体か, 雄 2 個体に限ら れ, 雌 2 個体が共存することはない（Asama and Yamaoka 2009）。アサリを宿主とするオオシロピンノでも 2 個体の 雌が入ることはないとされ, 雌同士が小さな容器に入れら れると闘争するとされている（杉浦ほか 1960）。これは形 態比較などの目的で採集したカリガネエガイBarbatia (Savignyarca) virescens（Reeve, 1844）を宿主とするヒラピ ンノArcotheres alcocki（Rathbun, 1909）を実験室に持ち 帰った際に, 複数個体の成熟䧳をシャーレなどに入れると 1 個体が残るまで，互いに歩脚などを引きちぎることから も確認できた (富岡ほか未発表)。一方, タイワンピンノ では 1 個体のソトオリガイから 1 3 個体のカニが記録さ れ, 雌も 2 個体まで採集されるが, 抱卵雌は 1 個体に限ら れるとされている (Hsueh, 2001a)。さらに，有明海のシオ フキガイ Mactra quadrangularis G. P. Deshayes in Reeve, 1954 を宿主とするカギッメピンノ Pinnotheres pholadis de Haan, 1835 では雌雄いずれも 2 個体以上が見いだされるこ ともあり, 甲長 $3 \mathrm{~mm}$ 以下の 9 個体が同時に寄居するケー スまで知られている（森田 1949）。一ツ葉入り江のフタハ ピンノではこのような複数寄生は $4 \%$ 以下であり, 極めて 例外的であった。また，その組み合わせはほぼ雌雄各 1 個 体であった。このようにカ二の種および宿主の大きさなど によって多少異なるが，いずれの場合も抱卵雌は 1 個体に 限られるようだ。抱卵雌の同種他個体に対する攻撃性や異 性間での共存性なども今後は検討する必要があろう。

一ツ葉入江ではイソシジミやオチバガイを宿主とするフ タハピンノへの多重寄生生物としてピンノヤドリムシ Heterocepon marginatum Shiino, 1936 が 13 例確認されてい るが (三浦ほか 2014)，この等脚類は原記載では下田産の シロピンノ Pinnotheres parvulus Stimpson, 1858 から報告さ れている（Shiino 1936）。他に，有明海のシオフキに寄生 するカギヅメピンノに関してはピンノヤドリムシの詳細な 生態が調べられ(森田1940), 幼生の形態変化 (森田 1949), 宿主の外部形態への影響（森田 1951）, 性分化 （森田 1952；1953b), 生活史（森田 1953a）および異常な寄 生状況（森田 1955）が報告されている。一ツ葉入江のフ タハピンノへのピンノヤドリムシの寄生率は極めて低いと 思われるが, 森田（1951）が示すように寄生状況によって は宿主の繁殖などにも影響することが判っているため, 今 後とも詳細な検討を行っていきたい.

謝辞 : 本研究の遂行に当たっては, 徳島県吉野川河口産のフタ ハピンノ標本を提供していただいた NPO 南港ウェットランドグ ループの和田太一氏に厚く御礼申し上げる。また, 第一著者が〉
タハピンノを見いだした際に同定の知識や文献をご教示いただい た西宮市貝類館の渡部哲也博士扔よび第二著者が走查型電子顕微 鏡を使用するに当たって, ご指導いただいた鹿児島大学機器分析 施設の久保臣悟氏，十川三臣氏に深く感謝する．查読者および英 文校閲者にあっては，著者らの不十分な論述を補う助言・修正意 見や文献紹介をいただき，深く謝意を表したい．

\section{引用文献}

檍地区郷土史編さん委員会 1990. 檍郷土史, 檍振興会, 宮崎, $1372 \mathrm{pp}$

Asama, H. and K. Yamaoka 2009. Life history of the pea crab, Pinnotheres sinensis, in terms of infestation in the bivalve mollusk, Septifer virgatus. Marine Biodiversity Records, 2 (e77): 1-5.

Campos, E. and R. B. Manning 2001. Authorship and diagnosis of the genus Arcotheres Manning, 1993 (Crustacea: Brachyura: Pinnotheridae). Raffles Bulletin of Zoology, 49: 167-170.

Christensen, A. M. and J. J. McDermott 1958. Life-history and biology of the oyster crab, Pinnotheres osterum Say. Biological Bulletin, 144: 146-179.

Hsueh, P.-W. and J.-F. Huang 1996. A new record of Pinnotheres bidentatus Sakai, 1939 (Decapoda: Brachyura: Pinnotheridae), from Taiwan. Crustacean Research, 25: 54-58.

Hsueh, P.-W. 2001a. Intertidal distribution, symbiotic association and reproduction of Pinnotheres bidentatus (Brachyura: Pinnotheridae) from Taiwan. Journal of Natural History, 35: 1681-1692.

Hsueh, P.-W. 2001b. Population dynamics of free-swimming stage Pinnotheres bidentatus (Brachyura: Pinnotheridae) in tidal waters off the west coast of central Taiwan. Journal of Crustacean Biology, 21 (4): 973-981.

Hsueh, P.-W. 2003. Responses of the pea crab Pinnotheres taichungae to the life history patterns of its primary bivalve host Laternula marilina. Journal of Natural History, 37: 1453-1462.

伊藤絹子 2002. 現場実験法により求めたイソシジミ Nuttallina olivacea の成長速度. 日本ベントス学会誌, 56: 9-17.

金丸文昭 1980。一以葉入江周辺植生調査報告. 宮崎県総合博物館 研究紀要, (6): 33-76.

三浦知之 2008. 干潟の生きもの図鑑，南方新社，鹿児島，197 pp.

三浦知之 2013. 宮崎県の干潟面積に関する試算. 宮崎大学農学部 研究報告, 59: 45-55.

三浦知之・森 和也 2008. 宮崎港一ツ葉入り江における鳥類の飛 来記録と採餌の状況およびコアジサシの営巣について. 宮崎大 学農学部研究報告, 54: 47-63.

三浦知之 ・ 大園隆仁・村川知嘉子・矢野香織 - 森 和也 - 高木正 博 2005. 宮崎港一ツ葉入り江に生息する底生動物と鳥類. 宮崎 大学農学部研究報告, 51: 17-33.

三浦知之・実政武志 2010. 宮崎県一ツ瀬川河口域に出現する貝類 と甲款類. 宮崎大学農学部研究報告, 56: 29-44.

三浦知之・宇都宮美樹・北嶋雄太・富岡 宏 2014. 海産甲殼類に 寄生する等脚目ヤドリムシ上科に関する宮崎県での初めての記 録 (予報). 宮崎大学農学部研究報告, 60: 29-39.

Miyawaki, D. and H. Sekiguchi 1999. Interannual variation of bivalve populations on temperate tidal flats. Fisheries Science, 65: 817-829.

森田眞一 1940. カクレガニ（Pinnotheres sp.）とそれに寄生する Bopyrid の一種 (Heterocepon marginatum Shiino) に就いての二三 の観察. 植物及び動物, 8(7): 76-80.

森田眞一 1949. Heterocepon marginatum Shiino (Bopyridae) の Cryptoniscus larva に就いて. 動物学雑誌, 58: 211-212.

森田眞一 1951. カギヅメピンノ（Pinnotheres cardii Buerger）の外 部形態に及ぼす Epicaridizationの影響について。動物学雑誌, 61: $48-52$. 
森田眞一 1952. Heterocepon marginatum Shiino（Bopyridae）に於け る雌雄性分化に関する実験的研究 - 1 ：成体雄の性の逆転につい て. 長崎大学学芸学部自然科学研究報告, 2: 54-59.

森田眞一 1953a. Heterocepon marginatum Shiino（Bopyridae）の生 活史について. 長崎大学学芸学部自然科学研究報告, 3: 14-20.

森田眞一 1953b. Pinnotheres cardii に及ぼす Epicaridizationの影 響 -2 : 生殖巣に及ぼす影響と二次性徴との関連について。長崎 大学学芸学部自然科学研究報告, 3: 13 .

森田眞一 1955. Heterocepon marginatum Shiino（Bopyridae）に於け る異常な寄生状況を示す 3 例とその性について．長崎大学学芸 学部自然科学研究報告, 4: 53-59.

Ng, P. K. L., D. Guinot and P. J. F. Davie 2008. Systema Brachyurorum: Part I. An annotated checklist of extant brachyuran crabs of the world. Raffles Bulletin of Zoology, Supplement, (17): 1-286.

Pearce, J. B. 1964. On reproduction in Pinnotheres maculatus (Decapoda: Pinnotheridae). Biological Bulletin, 127: 384.

Pearce, J. B. 1966. The biology of the mussel crab, Fabia subquadrata, from the waters of the San Juan Archipelago, Washington. Pacific Science, 20: 3-35.

Roth, B. 1978. On the identification of three Japanese speceis of Nuttalia (Mollusca: Bivalvia). Japanese Journal of Malacology, 37: 223229.

Sakai, K. 2000. On the occurrence of three species of crabs on Shikoku Island, Japan, and a new species, Pinnotheres taichungae nov. spec., from Taiwan (Decapoda, Brachyura). Crustaceana, 73(9): 1155-
1162, figs $1-3$.

Sakai, T. 1939. Studies on the crabs of Japan, IV. Brachygnatha Brachyrhyncha, Yokendo, Tokyo, pp. 365-741.

Shen, C. J. 1932. The brachyuran crustacea of north China. Zoologia Sinica, Peiping, Series A, 9: 1-320.

Soong, K. 1997. Some life history observations on the pea crab, Pinnotheres tsingtaoensis, symbiotic with the bivalve mollusk. Sanguinolaria acuta. Crustaceana, 70: 855-866.

杉浦靖夫・杉田昭夫・木原正光 1980 . アサリ養殖における有害動 物としてのカクレガニの生態 -I. アサリ Tapes japonica に共生 するオオシロピンノ Pinnnotheres sinesis の生態とアサリの実入 りにおよぼす影響について. 日本水産学会誌，26: 89-94.

Sun, W.-M., S.-C. Sun, Y. Wang, Y. Baowen and W. Song 2006. The prevalence of the pea crab, Pinnotheres sinensis, and its impact on the condition of the cultured mussel, Mytilus galloprovincialis, in Jiaonan waters (Shandong Province, China). Aquaculture, 253: 57-63.

氏野 優・三浦知之 2011. 宮崎県一ツ葉入り江で採集されたアシ ベマスオガイ。ちりぼたん，41,134-137.

渡部哲也 2012. カクレガニ科フタハピンノ.日本ベントス学会 (編), 干潟の絶滅危惧動物図鑑, 東海大学出版会, 秦野, 128 pp.

Yamada, C., G. Itani and H. Asama 2009. Utilization of the non-indigenous green mussel, Perna viridis, by native pinnotherid crab Arcotheres sinensis in Uranouchi Inlet, Kochi, Japan. Crustacean Research, 38: 70-76. 